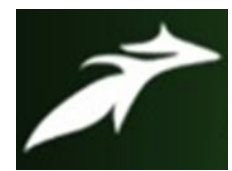

Gaurav Kumar et al, International Journal of Advances in Agricultural Science and Technology,

Vol.7 Issue.10, October-2020, pg. 15-20

ISSN: 2348-1358

Impact Factor: 6.057

NAAS Rating: 3.77

\title{
Sustainable and Healthy Organic Goat Farming
}

\author{
Gaurav Kumar'; Sandeep Yadav²; Dhawal kant Yadav'; Manmohan Singh Rajput ${ }^{4}$ \\ ${ }^{1}$ PhD Scholar, Animal Physiology Division, NDRI, Karnal, 132001 \\ gauravyadav1725@gmail.com \\ ${ }^{2}$ M.V.Sc Scholar, Vety Medicine, LUVAS, Hisar, 125001 \\ drsandeepyadav2005@gmail.com \\ ${ }^{3}$ PhD Scholar, LPM Section, NDRI, Karnal, 132001 \\ dhawalyadav777@gmail.com \\ ${ }^{4}$ PhD Scholar, LPM Section, NDRI, Karnal, 132001 \\ drmohanrajput@gmail.com
}

\section{Introduction}

Organic production is the way agricultural products; food and fiber are grown and processed. Certified organic- the items that have been grown according to strict uniform standards that are verified by independent state or private organizations. Organic livestock standards include difference in species, disagreements about animal health and welfare and more issues open to interpretation. Before going Organic we should decide which part of your sheep and goat enterprises is going to be organic; meat, milk, fiber, Identify a source of organic feed, supplements and bedding. Find a veterinarian who will treat your organic livestock, Identify a processing plant that is certified for organic slaughter Identify potential market for your organic meat, milk or fiber.

\section{Organic Livestock Farming}

A system of livestock production that promotes the use of organic and biodegradable inputs from the ecosystem. Deliberately avoids the use of synthetic inputs such as drugs, feed additives and genetically engineered breeding inputs. Codex Alimentarius (2007) 


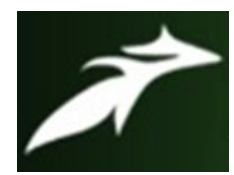

Gaurav Kumar et al, International Journal of Advances in Agricultural Science and Technology, Vol.7 Issue.10, October-2020, pg. 15-20

\section{Organic Principles (IFOAM 2005)}

1. Principle of health

2. Principle of care

3. Principle of ecology

4. Principle of fairness

Global India ranks 9th in Organic Farming Outlook. The share of nations involved in organic farming, according to International Federation of Organic Agriculture Moment (IFOAM), leaves India at ninth rank with Australia on top with 22.7 million hectares of land used for organic farming, Indian agriculture is characterized by small scale $(<2$ ha $)$, subsistence farming operations under low input low output production systems, where livestock are essentially integrated with crop farming. Thus, alongside organic crop production, the prospects of livestock production are bright through yet to be explored In India, Uttarakhand is the pioneering state in organic agriculture, since it is the first state declared as organic. Here the state government has identified 'organic farming' as a thrust area for agriculture development and promoting organic farming through establishment of an institutional mechanism named as Uttarakhand Organic Commodity Board (UOCB) which was created on 19 May 2003.

\section{Standards and Certification Agencies}

- $\quad$ The Codex Alimentarius Committee -2001.

- In India, in 2000 the National Programme for Organic Production (NPOP), ECOCERT (an inspection and certification body), APEDA (Agricultural and Processed Food Products Export Development)

- 2001, the National Accreditation Programme was notified by the Ministry of Commerce. • Codex Alimentarius

- NSOLP - National Standards for Organic Livestock production in India 


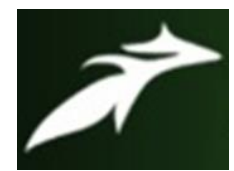

Gaurav Kumar et al, International Journal of Advances in Agricultural Science and Technology, Vol.7 Issue.10, October-2020, pg. 15-20

\section{Systems followed for Goat Rearing by Organic Producer}

NAAS Rating: 3.77

1. Rotational system where housing is provided in different paddocks . Goats are moved frequently or seasonally. This prevents building up of parasites to the environment from overgrazing

2. Provision of shelter and a large exercise area, where feed and browse are brought to the animals . Goats should always be allowed plenty of space for running and jumping.

3. A goat barn with access to different grazing areas . In winter animals are confined to a smaller outdoor exercise area . Barns should be well ventilated and be kept dry with plenty of bedding . Goats are generally quite hardy animals if fed adequate fiber.

\section{Requirements for Organic Production of Goat Products}

Sheep and goats sold for organic meat must be raised under organic management from the last third of gestation through slaughter. Fibreproducing animals must be fed and managed organically from the last third of gestation. In order to sell organic milk, all production animals must be fed and managed organically for the previous 12 months. Rams and bucks do not need to be certified organic unless they will be sold as slaughter animals or used for fiber production. The offspring from females that are used to produce organic milk (or fiber) do not need to be raised organically.

\section{PROHIBITED}

- Organic breeding animals cannot be brought in and out of organic production.

\section{PASTURE AND LIVING CONDITIONS}

Access to outdoor, Access to pasture, Minimum of 30 percent of DMI from grazing for at least 120 days in a calendar year, Access to shade and shelter. 


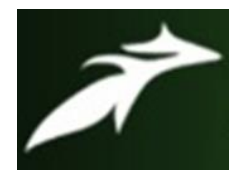

Gaurav Kumar et al, International Journal of Advances in Agricultural Science and Technology, Vol.7 Issue.10, October-2020, pg. 15-20

Temporary confinement, Feeding areas (yards,pads, and lots ) during nongrazing season allowed.

\section{Housing Requirements}

- Express natural behavior

- Non-organic bedding

- Minimum space

- No Overcrowding

- Ventilation, fresh air

- Adequate Lighting, Bedding

\section{Feeding Organic Goats}

Suitable feed materials are selected based on availability in the locality, nutrient requirements and PNS standards. Feed materials are prepared following PNS procedures. Maintenance of forage area are administered in accordance with PNS procedures. Animals are fed based on feeding management program of PNS. Feeding is monitored following PNS procedure.

\section{MANAGING DOES AND PROGENIES}

Care of Pregnant Doe (She-goat). Protein supplements are important during the dry period (non lactating period). This is because the kids are growing faster at this time. If you have been feeding legumes which are high in calcium its best to replace these with high energy feeds (e.g. hay) at least three weeks before kidding to prevent milk fever. This forces the doe to mobilize its own body stores and prepare for milking. Deworm the doe two weeks prior to kidding. A goat requires 3\% (of its body weight in dry matter approximately $1.5 \mathrm{~kg}$ ) per day or $5 \mathrm{~kg}$ of fresh materials should be availed to the doe per day. The complete meal should comprise of both the protein and energy feed. 


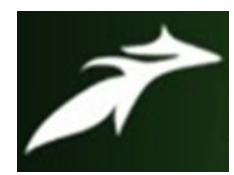

Gaurav Kumar et al, International Journal of Advances in Agricultural Science and Technology, Vol.7 Issue.10, October-2020, pg. 15-20

Provide the does with salt lick and at least either half a kilo of dairy meal per day or a mixture of pollard and bran. Provide adequate clean water all the time.

\section{Care of Lactating Doe}

At the end of the 5th month, check for the following signs of approaching birth; Reduced feed intake, Rapid breathing, Doe will constantly look back unto her sides as if expecting to see young ones. Enlarged udder that may or may not discharging colostrum. Swollen vulva and thick mucus discharge from the vulva. The hair around the tail and the rear should be clipped and fresh beddings (straw or grass) provided. The kid is born after short labour but in case of difficult kidding expert should be consulted.

\section{SELECTING HEALTHY BREEDERS}

A healthy and good quality buck (he goat). The buck must be healthy, strong and should have a well-developed body frame. It must be of productive breed. It must have normal sexual organs and well developed testicles. The buck must be selected from does that produce a high volume of milk and are prolific. Control mating i.e. Limit the number of does per male (the recommended ratio is 1 male for 35 does). The Buck must be free of any physical defects e.g. undershot jaws, overshot jaws. It should have a strong masculine head and neck and noisy and should seek out females on heat and mate them. If it's shy and timid it should be culled. Badly worn teeth indicate old age. Males with split, missing or worn teeth should not be selected for breeding as they are physically unable to browse or graze properly. Legs should be checked for deformities and hooves trimmed.

\section{CONCLUSION}

An Organic Agriculture is incomplete without an Organic Livestock. The strengths \& opportunities are clearly much more in number \& value than threats and weaknesses. So, India should go for an organized organic goat farming. Organic goat production can improve animal welfare, protect the environment, and sustain rewarding rural lifestyles. Traditional and alternative medicine holds the promise for alternative 


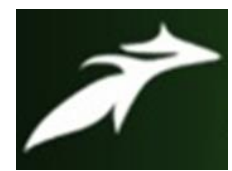

Gaurav Kumar et al, International Journal of Advances in Agricultural Science and Technology, Vol.7 Issue.10, October-2020, pg. 15-20

prevention and treatment of animal diseases. The future of organic goat production is to continue searching for alternatives that are environmentally friendly, human health conscientious and animal considerate. Understanding organic goat farming from economic, ecological, and animal welfare perspectives will increase the likelihood of success. Organic goat production will have to strive for a more sustainable system than the conventional one, offsetting the increased costs of organic goat production by higher product prices, and certified organic goat products that are healthier than those conventionally produced. 